\title{
Black Bodies, White Bodies - 'Gypsy' Images in Central Europe at the Turn of the Twentieth Century (1880-1920)
}

\section{Éva Kovács}

kovacs.eva@tk.hu

Institute of Sociology, Center for Social Sciences, Budapest, Hungary

Vienna Wiesenthal Institute for Holocaust Studies, Vienna, Austria

ORCID: https://orcid.org/0000-0002-4280-9794

Éva Kovács, PhD, studied sociology and economics at the universities of economics in Pécs and Budapest, PhD 1994, Habilitation 2009. She is Deputy Director at the Vienna Wiesenthal Institute for Holocaust Studies (VWI) and is Research Professor at the Institute of Sociology at the Center for Social Sciences in Budapest. Her research fields include visual studies, community studies, research on memory and remembrance, as well as ethnic identities in East Central Europe. She has authored five monographs, edited nine volumes, and published numerous articles in peer-reviewed journals. She founded the digital audiovisual archive 'Voices of the Twentieth Century' in Budapest and was co-curator of the exhibitions on 'Myths of the Nations' at the German Historical Museum in Berlin, the 'Representation of Roma and Sinti' in Kunsthalle Krems, 'Contemporary Roma Art' in Collegium Hungaricum, and on cultural opposition under state socialism in Bratislava, Budapest, Prague, Vienna, and Warsaw. She is a member of the Curatorial Board of the European Roma Cultural Foundation and a member of the Editorial Board of Critical Romani Studies.

\section{CDS Critical}

Romani Studies 


\section{Abstract}

The problem of the observer has long been a key concern of social theories. However, in mainstream sociology, it was not until three decades ago that the relationship between image and text, seeing and gaze, appeared on the horizon of the discipline. Studying the visual representation of Roma in Modernity, one sees how Central European societies create their own sexualised and feminised Blackness through 'savage' groups and individuals. The central thesis of the article is that, across Europe, the panoptic regime of Modernity operates with the optical unconscious in two ways. On the one hand, by re-visualising social differences that became invisible after the collapse of feudal society; on the other, by bringing the oppressed into sight and rendering the oppressors invisible. However, there is a significant difference between the Western and Eastern European representations of 'savages': in the process of nation-building, the 'Gypsy' became an ambiguous part of the national imaginary in Eastern European countries. The paper argues that ideas and visual representations of Roma commuted between Central and Western Europe resulted in tensions between the colonial and emancipatory gazes.

\section{Keywords}

- Central Europe

- Colonial gaze

- Emancipatory gaze

- Modernity

- Painting at the turn of the nineteenth century

- Visual representation of Roma 


\section{Introduction}

The following thought experiment was occasioned by an invitation to curate an exhibition titled 'Representation of "Gypsies" in Modern Painting' in the Kunsthalle of Krems (Austria) more than ten years ago (Baumgartner and Kovács 2007, 2008; Kovács 2009). I discovered certain connections of interest to those concerned with the archaeology of images during a course of intensive preparatory research. ${ }^{[1]}$ This article revolves around two key categories: the optical unconscious (Benjamin 1980) and the panoptic regime of Modernity (Foucault 1995), by no means excluding the possibility that the representation of Roma ('Gypsies') ${ }^{[2]}$ in nineteenth- and early-twentieth century painting can be approached in radically different ways.

This essay reflects the position of a sociologist interested in visual studies. My knowledge lies in the representation of Otherness from studies of Central European Jewry from the nineteenth to twentieth centuries. It was in the early 1990s that I read The Jew's Body (Gilman 1991). In this book, Sander L. Gilman analysed anti-Semitic rhetoric with the help of case studies on Jewish body and mind, creatively combining medical and historical approaches. I was impressed deeply by this book, so I read Gilman's other writings, including Black Bodies, White Bodies: Toward an Iconography of Female Sexuality in Late Nineteenth-century Art, Medicine, and Literature (1985), the line of argument of which I attempt to follow in this essay. I also became familiar with two important books by Georges-Didi Huberman: Invention of Hysteria (2004) and Opening up Venus (1999). As far as I know, these two favourite authors of mine never referred to each other's works; nevertheless, I connected

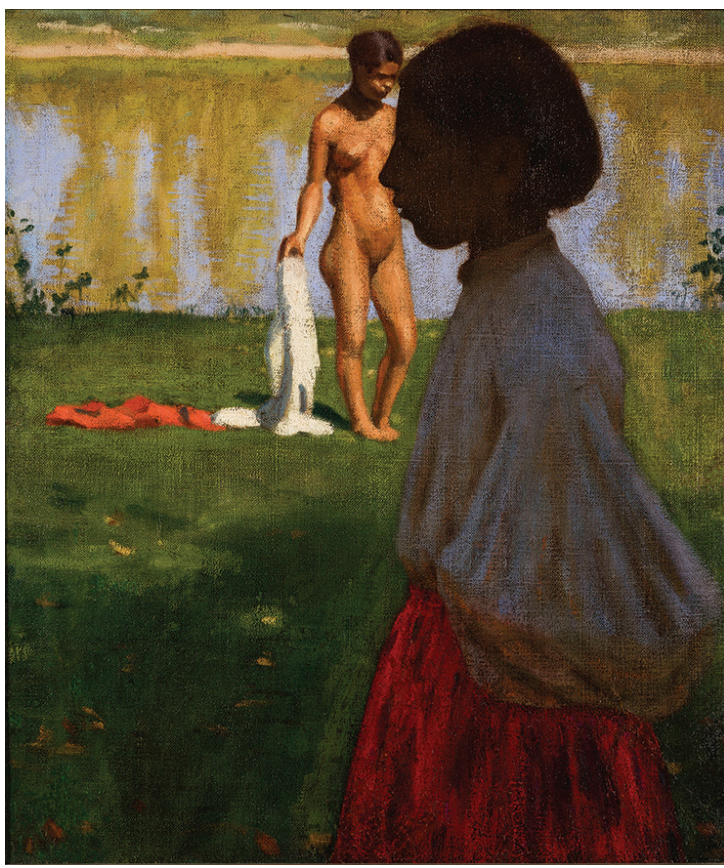

Figure 1.

János Göröncsér Gundel, Gypsy Girl and Nude Model, c. 1907, oil on canvas, 69 x 59 cm, Hungarian National Gallery, Budapest.

1 The whole corpus of paintings I studied - approximately 500 pieces - contained pictures from the Renaissance to the twentieth century from Portugal to Romania and from Great Britain to Italy. In this paper, I will only discuss a collection of approximately 100 paintings made by Central European artists in the four to five decades around 1900. Although all of my hypotheses were tested on many works of Austrian, Czech, German, or Romanian painters, I will use Austrian and Hungarian examples, not just because I know this corpus better but also because of practical copyright issues. The reader can check my hypotheses with the help of the catalogue from our exhibition (Belgin and Baumgartner 2007).

2 In this paper, I use the word 'Gypsy', that was a pejorative term in the era under scrutiny, between single quotes, while the term of Roma (and Sinti) refers to the current self-definition of this people. 
them in order to interpret both the images and texts that crossed my path during preparations for the exhibition. Still, had I not encountered János Göröncsér Gundel's painting, Gypsy Girl and Nude Model, my ponderings might never taken shape (Figure 1). Looking at the picture by this artist who died at the age of 27 in 1908, I felt a picture emerging in my mind, too. I will analyse this painting in detail later.

Visual conventions take a wide range of forms, styles, and icons in Western aesthetic cultures. All these manifestations define the locations (statuses) and qualities taken by the individuum in society. Hence, visual conventions can be grasped in representations. For the social scientist, representations of science, the arts, or everyday life share the same status, inasmuch as they are all based on experienced or observed reality. However, the history of vision is not merely the history of representations; it also encompasses the history of the status of the observer at the intersection of relations between the body and forms of institutionalised discursive power (Crary 1990).

This is not to contradict the notion that gaze is a primary process of perception and interpretation. The knowledge and understanding of practices that were used to transform things into images belongs to suppressed knowledge one wants to re-establish. The perception of images takes place via an 'act of metamorphosis', in which the images seen are transformed into remembered images and find a new place in our image memory (Belting 2001). Belting writes, 'We are used to thinking of gaze and image as separate, and therefore we speak of looking at an image. (...) however, images form in adapting the gaze. The complicity between body and gaze leads to the image' $(2012,187)$.

It is an experience that one is not necessarily aware of; instead, it often remains in the optical unconscious, in a visual dimension of the material world filtered out and rendered invisible by social consciousness. As Walter Benjamin wrote about the gaze of the camera, it introduces us to unconscious optics as does psychoanalysis to unconscious impulses. The camera reveals aspects of reality that register in our senses but never quite get processed consciously' (Benjamin 1980, 500; Hárs 2006). My central thesis is that the panoptic regime of Modernity operates with the optical unconscious in two ways across Europe: on the one hand, by re-visualising social differences that became invisible after the collapse of feudal society in the nineteenth century; on the other, by bringing the oppressed into sight and rendering the oppressors invisible (Foucault 1995). ${ }^{[3]}$

I will support my central thesis with the following arguments: (1) in European Modernity the Black body becomes sexualised and feminised, while also masculinised inasmuch as the white society projects its desire and discontent onto the Black feminine or masculine body; (2) adopting Western patterns in the visualisation of social and ethnic differences, Central European societies create their own Blackness

3 Here, for reasons of space, I cannot delve into the recent literature on the subject. I would only like to stress the interconnection between gaze and optical unconsciousness in experiencing social segregation in a broader sense: 'The idea of a gaze that belongs to the other, a component of Benjamin's understanding of the optical unconscious, was also central to Du Bois's experience of double consciousness. For Du Bois, racial consciousness was a visual dynamic, an effect of an exterior gaze, and his concept names the psychic strain that African Americans experienced living in a segregated world: 'It is a peculiar sensation, this double consciousness, this sense of always looking at one's self through the eyes of others' (Smith and Sliwinski 2017, 14). 
through 'savages' and their faraway and nearby colonies (Piotrowski 2009; Buck-Morss 2011). In the Panopticon of Central European Modernity, 'Gypsies' become pendants of the African and Asian 'primitives' of Western Europe.

\section{1. 'Blacks' along the Banks of the Seine}

Gilman's enigmatic illustration of his thesis takes us back to nineteenth-century Paris, directly in front of Edouard Manet's Olympia (Gilman 1985). The history of this painting is well known: following Tizian and Giorgone, Manet 'only' meant to paint a beautiful Venus. The main figure of Olympia, rather bare than naked, with her provocative glance at the viewers, stirring them from their comfort, caused such outrage that the painting finally was removed from the Paris Salon. Visitors regarded it as an apology of prostitution, mocking Olympia as a yellow-bellied Odalisque, a Venus with a cat, a sort of female gorilla. Gilman draws attention to the fact that - besides other iconographic elements in the picture - Olympia's figure is sexualised primarily through the Black maid. Gilman considers Olympia to be an empty object that acquires its meaning from the Black body that imparts promiscuity on the white body.

The prostitute represents the essence of female sexuality, in particular, a passionate and sick sexuality whose psychology and physiognomy was studied thoroughly in this period (Parent-Duchâtelet 1837). ${ }^{[4]}$ It was in the nineteenth century that the perception of the prostitute mingled with that of Blackness: the pathology of the female body was seen as the representation of primitive social life, regression, and thus insanity or unrestrained and uncontrollable sexuality. For this to happen, both prostitution and Blackness had to be displaced from their previous social positions and set out in new directions of popularisation and reflexivity (Bernheimer 1997; Lestringant 1997).

Owing to modern medicine and biology, the sexus of the Black woman and man became iconic for deviant sexuality. A formative experience of colonial cultural history has been researched meticulously since the exhibition of the Hottentot Venus, i.e. Saat-Jee Baartman, a slave San woman from South Africa (Bitterli 1976; Schultz 1999). ${ }^{[5]}$ The event, by the way, barely stood out in a world of habitual Völkerschaus ${ }^{[6]}$ culminating in the vogue nègre that turned into negrophilia by the early twentieth century (Gombrich 1999). Saat-Jee's European short story differs from the conventional Völkerschaus of her time, mainly in that she was not exhibited as an example of 'savage tribes' among her kin members in the context of a 'tribal world' - to be sure, she appeared at the ball of the French government - but as a Black woman with 'abnormal' proportions. This allowed for her involvement with or, rather, incorporation into white society as a visible physical being. It also meant that her presentation

4 Besides Germany, the idea became pervasive in Hungary as well (Cséri 1893). See also Schlor (1991).

5 The story has been thoroughly discussed in feminist and postcolonial literature (Bloom 1999; Sharpley-Whiting 1999).

6 Exhibitions of extra-European people in zoos were common civic attractions up until the 1930s. For instance, 250 members of Sudanese and Congolese tribes were exhibited in the Budapest Zoo for Hungarian millennium celebrations (Mathez, Froidevaux, Földessy, and Szántó 2008; N. Kovács 2008). 
- as opposed to exhibitions of the Congolese, Inuit, and Senegalese - was limited explicitly to the aggrandisement of her sexual organs. As Gilman puts it, the public was watching her breasts and buttocks, while fantasising about her vagina (1985, 235-237). The fact that this did not happen to an Inuit corresponded to the European tradition of sideshows spanning several centuries. That tradition may be seen as a kind of self-disciplining practice in a society exhibiting its own ill people, dwarfs and 'lunatics' looking 'extraordinary' or 'abnormal'. Using Saat-Jee Baartman as a spectacular object reveals that, paradoxically, white society perceived Blacks to be actually very close to themselves. The bare reality of the derogatory treatment of Saat-Jee was a way of recognising and attempting to eliminate this proximity. It was transparent in contemporary culture as well as in the incipient discipline of anthropology at the time. ${ }^{[7]}$ Negrophilia went hand in hand with negrophobia. ${ }^{[8]}$

By the nineteenth century, the images of prostitutes were projected onto Black people: important thinkers of the time such as Hegel or Schopenhauer attributed uncontrollable sexuality, primitive social life, and, consequently, a greater inclination to regression to Black people. The next generation of theorists only had to push this a little further to associate insanity or unrestrained sexuality with Blackness and femininity. Hence, Blackness was introduced in medical discourse as a pathological symptom.

\section{First Detour: The Aesthetics of Hysteria}

Prejudices concerning female sexuality in the nineteenth century were not so different from those ingrained in previous centuries (i.e. in comparison to men, women's sexus is inferior, female genitalia are more primitive, and female sexuality is predominantly anal); however, these prejudices became invested with radically new meanings owing to the expansion of representations as well as the revolutionary changes in medicine and natural sciences during this period.

The visualisation of mentally ill women reached a peak in the last third of the nineteenth century with the help of photographs made in the hospital of Salpêtrière. ${ }^{[9]}$ In the 1870 s, more than 4,000 women diagnosed with incurable diseases or mental illnesses received treatment there. The ward of hysterical patients, directed by the imminently famous Jean-Martin Charcot, was considered especially spectacular. Regular examinations, theatrical Tuesday shows where chronic cases were

7 The history of the 'Hottentot Venus' has a huge literature. See e.g. Willis 2010. For a critical analysis of the place of black female body within American culture, see Wallace-Sanders 2002.

8 Negrophilia (from French negrophilie) is the term of adapting and popularising 'Black' culture into the 'white' society of Paris in the early 1900s. See Archer-Straw 2000. Frantz Fanon's classical auto-theoretical work Peau noire, masques blancs (Black skin, white masks) was published in 1952. In this book, Fanon analysed the colonised psychic constructions of Blackness. For negrophobia, see Thomas 2007.

9 Didi-Huberman writes: The Salpêtrière was the Mecca of the great confinement, known locally as the 'little Arsenal', and was the largest hospital in France. It was another Bastille, with its 'courtyard of massacres', 'debauched women', convulsionaries of Saint-Médard, and 'women of abnormal constitution' confined all together. It was the general hospital for women, or rather for the feminine dregs of society; 'physicians of the Hôtel-Dieu were even forbidden to receive and treat them', for women with venereal diseases, among others, were 'gathered up' only at the Salpêtrière. They were whipped on arrival, the 'punishment certificate' was completed, and they were interned. The largest hospital in France was the hospice for women. One must imagine, or try to imagine the Salpêtrière, in Paris itself, as such an improbable place of femininity - I mean it was a city of women, the city of incurable women $(2003,13)$. 
presented to the public, including some of the most distinguished medical doctors, scholars, politicians, and artists of the age, in a so-called amphitheatre - just like the recording of these events in the photographic series - reflected a kind of mediatised image of sick female sexuality, calling for the disciplinary and controlling power of the men's world. 'If everything seems to be in these images, it is because photography was in the ideal position to crystallize the link between the fantasy of hysteria and the fantasy of knowledge' (Didi-Huberman 2003, xi). ${ }^{[10]}$ Such positioning of the female body, detached from space and time and deprived of identity was perfectly apt to condense the various images of women, the 'other', and those with unstable moral identities (prostitute or criminal) in a single image, in which the nude does not look back anymore but deflects herself from her own body. ${ }^{[11]}$

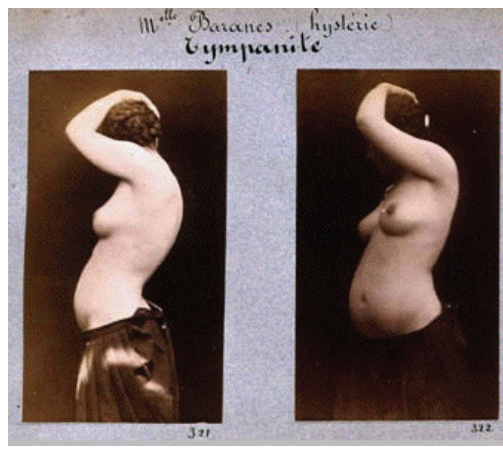

Figure 2.

Albert Londe, Mlle Banares (hystérie); Tympanite, c. 1883, toned gelatine silver, 35.5 x $47 \mathrm{~cm}$, collection Texbraun.

After cross-reading Gilman's and DidiHuberman's texts and studying Central European Romani representations at the turn of the nineteenth century, let me raise this question: considering the iconography of the image of the hysterical female body, i.e. viewing it not in terms of Roland Barthes's (1981) studium but rather in those of punctum, is there a significant difference between two particular photographs:

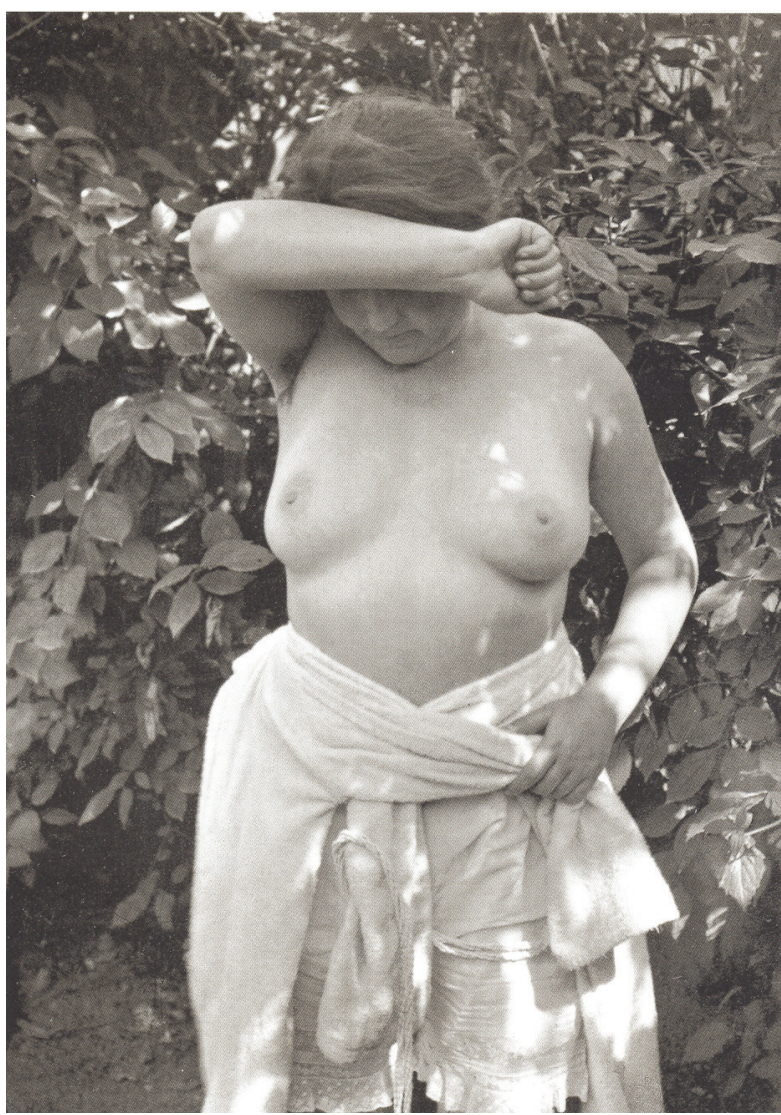

Figure 3.

André Kertész, Untitled, Abony, 1921, glass plate, 4.5 x $6 \mathrm{~cm}$, Ministére de la Culture (AFDPP), France.

10 Attempts were made in Hungary to explore this phenomenon, too, although not following Didi-Huberman but providing in Foucault's vein, some significant analogies between the French and the Hungarian cases (Lafferton 2003; Kövér 2005).

11 For the debate on hysteria in art and photography, see Steer 2017; Timpano 2017. 
Tympanite by Charcot's clinical photographer Albert Londe (Figure 2) and an early untitled work by André Kertész probably showing a Gypsy girl from the Hungarian village of Abony (Figure 3). In spite of remarkable differences between them regarding the backgrounds (blank studio versus sunlit lilac bushes), the poses of the women (side versus frontal), the visibility of their faces (totally obscured versus a visible lower half), and their physical gestures (covering their face with one hand while they hold onto their clothes with the other), they show significant similarities because both condense the image of shame and the 'hysterical' female body.

\section{Second Detour: Criminalisation of 'Black' and 'Gypsy'}

Criminal anthropology was born as a discipline by the mid-eighteenth century, and it swiftly arrived at the Austro-Hungarian monarchy - and also contributed to the precepts of Nazi racism (which, thanks to feminist and postcolonial criticism, does not need to be presented here in detail) that summarised the 'phantasy of knowledge' described above. Particularly horrific examples in which distinct types of social otherness could be encapsulated in a single image are provided in the work of Guglielmo Ferrero and Cesare Lombroso (2004; see also Mátay 2005). In the portrait gallery of born criminals - i.e. groups of perpetrators to be prosecuted - the 'Black' and the 'Gypsy' appear next to the prostitute and the hysterical. Paradoxical as it may seem, images of body, gender, sin, deviance, and ethnicity were so confluent that - when sufficiently justified by nascent racial theory - they had the power to transform the essentially feminine nature of hysteria, as it had been considered since antiquity, to become a male attribute. A man could just as well be hysterical as long as he happened to be, for instance, a Jew (Gilman 1991, 61-103) or (as will be explored in the following section) a member of another marginalised or stigmatised community like Roma in Central Europe. ${ }^{[12]}$ An interesting example of both the transformation of an ethnicised, criminalised, and gendered imaginary into the representation of Roma and Jews and the mediatising of that transformation between East and West is a book written by Austro-Hungarian composer Franz/ Ferenc Liszt, Des Bohémiens et de leur musique en Hongrie, which was published in Paris in 1859 and republished in 1881. As a counterpoint to freedom-loving Roma, he devoted one seventh of the book to another 'nationless' people, Jews, ${ }^{[13]}$ in a way that was completely unrelated to the subject of music (see also Hamburger 2011; Gelbart 2019).

These examples come from the mainstream of the era: they do not refer to sensational events of the time, even though their sensational aspects travelled all over Europe through the contemporary press; these

12 The representation of Otherness has an enormous sociological literature from Georg Simmel to current postcolonial or feminist authors that would stretch the theoretical framework of the study. However, I would like to express my special thanks to one of the reviewers for drawing my attention to contemporary art theory debates on Otherness in Modernity. As e.g. Piotr Piotrowski argues for a 'horizontal history' of European art: The non-European 'Other' is a real 'Other', while the Central or Eastern European Other is a 'not-quite-Other' or a 'close Other'. (...) In modern culture, however, the place of the 'close Other' is on the margins of European culture, outside the center but still within the same cultural frame of reference, while the place of the 'real Other' is determined not by the strategy of marginalization, but by that of colonization (2009, 52-53; see also Pejić 1999).

13 Another example from Illustrated London: 'The Gipsies - who of us has not at one time or other, paused to watch and wonder at these picturesque and mysterious wanderers - the most widely-diffused race, not excepting even the Jews, on the face of the earth?' ('The Roumany-Char or Gipsies', 28 September 1856, a correspondent, p. 304, quoted by Gilman 2001, 61). 
are practices and ingrained images, embodiments of ideals, which remained pervasive as part of the institutional world of Modernity for two centuries.

\section{3. 'Savage' People on Hungarian Riverbanks}

What do events by the Seine or the Thames have to do with those taking place by the rivers of the Carpathian Basin? As a matter of fact, there were Völkerschaus, or side shows, in Budapest which, like their counterparts in the West, shared ideas on the social stigmatisation of prostitution and hysteria, the social theory of criminology, or the incessant attraction to, incorporation of, and violent severance from the 'Other'. The salons of Austrian, Bohemian, Czech, and Hungarian middle- and upper-class homes also were decorated with works portraying 'our savages'. For example, a 'Gypsy' painting by Hungarian artist István Csók used to hang on the wall of the Gellért Bath Hotel, one of Budapest's most elegant establishments. Since the end of the eighteenth century, Romaphobia and Romaphilia - as negrophobia and negrophilia in Paris - have marched hand in hand in the Carpathian Basin.

\section{Third Detour: Illustratio Hungariae}

There is, however, a remarkable difference between the representation of 'savages' imported from colonies and domestic ones; let me call it Illustratio Hungariae (Miskolczi 2008). This is not simply about diverse pro-Gypsy sentiments and a romantic Gypsy cult opposed to essentialist antigypsyism - because such a contrast can just as well be found in representations of Blackness. Rather, Illustratio Hungariae means that 'Gypsy' became an ambiguous part of Hungarian national imaginary in poetry, music, and the arts including popular genres (Hegedűs 2002; Szuhay 2002; Oros-Kelementisz 2008).

A notorious example is the 'musician Gypsy' whose figure entails a kind of carnivalesque transformation of Romani people (Altorjai 1978 [1736]). Obviously, this move could not result in the transgression of social boundaries but only in their momentary suspension. Its most typical instances include 'Gypsy clowns' in sixteenth century iconography and their modern counterpart, the 'Gypsy musician', entertaining gentlemen, sitting next to the king, taking princesses for mistresses and being a master of pain and sorrow. We know of prominent musician-singers who were assimilated beyond recognition into 'noblemen' in some of the paintings of the time, their excellence being thus predicated upon their non-Gypsy look. It should be noted that the European perception of Hungarians contributed to this ambiguity: viewed from Vienna, Berlin, or Paris, 'Gypsy music' was identified as Hungarian music. As Franz Liszt defined himself in a letter: 'On me définirait assez bien en allemand Zu einer Hälfte Zigeuner, zur andern Franziskaner' [In German, I probably would be defined as half-Gypsy and half-Franciscan] (La Mara 1899, 316; see Hamburger 2011).

The historicising approach presents the image of Gypsy troops participating in the 1848 Hungarian War of Independence as naturalised Hungarians. These Gypsy figures serve to preserve the memory of lost battles and dissipating national dreams in poetry. For example, in Vén cigány (The old Gypsy), a famous poem by Mihály Vörösmarty, the figure of the historicised and naturalised 'Gypsy' is a projection of the poet's own national identity as the patriotic nobleman masked himself as an old 
Gypsy musician. ${ }^{[14]}$ These romantic representations show 'the Gypsy' in accordance with Rousseau's enlightened ideal of society. The ubiquitous compositions of 'three Gypsies', so popular in the period's painting, are allegories of an idyllic primordial condition that, although much desired, is unattainable for the 'civilised man' - a world where bourgeois society cannot return anymore. In sum, the triads are allegories emancipating or glorifying not Romani people, as it were, but a natural condition that is only conveyed by the 'Gypsy'.

To our eyes these people seems to lead what is practically an animal existence (...) A race having neither any religion nor any law, any definite belief or any rule of conduct; holding together only by gross superstition, vague custom, constant misery and profound abasement; yet obstinately persisting, in spite of all degradations and deprivations, in keeping its tents and rags, its hunger and its liberty. It is a people who exercises on civilised nations a fascination that is as hard to describe as to destroy; passing, as it does, like some mysterious legacy, from age to age; and one which, though of ill-repute, appeals to our greatest poets by the energy and charm of its types (Liszt 1859, quoted by Kligman 2001, 61).

Thus, by the end of the nineteenth century, 'Gypsy' becomes a demonstration of patriotic joy and sorrow in Central Europe. Besides the erratic ways of fashion, a wide range of facts from social history explain this phenomenon. Miskolczy stresses that mandatory military service introduced by Emperor Joseph II (1780-1790) contributed to a greater visibility of 'Gypsies' in the monarchy and made them appear in larger groups and from new perspectives. Other authors associate the iconographic turn with the 'civilisatory' measures issued by Maria Theresa (1740-1780). It is more likely that even larger social powers were at work during the merging of the images of the 'Gypsy' and the nation. As revealed by Miskolczy's study, the development of Hungarian national identity paused (i.e. after defeat in the 1848 War of Independence) exactly when the image of the 'Gypsy' started to convey a sense of patriotic joy and sorrow in the language of empire. To a certain extent, the diversity of the Habsburg Empire was due to the many languages and cultures of its peoples; but this diversity was also produced by the empire itself in order to expand its control over various ethnic groups (Feichtinger, Prutsch, and Csáky 2003; Klement, Miskolczy, and Vári 2006). This artistic, cultural, and political production of diversity allowed the designation of 'Gypsy' to stand for and visualise, pars pro toto, a kind of people, while at the same time relegating Gypsies to the physical and mental periphery of society and, vice versa, interpreting peripheral situations as typically 'Gypsy’ phenomena.

\section{Bodies Driven out, 'Denigrated' and Eliminated: 'Gypsies' by the Seine, Foreign Artists on the Banks of the Tisza}

August von Pettenkofen and Johann Gaulbert Raffalt were renowned Austrian landscape and genre painters in the nineteenth century. As a war correspondent, Pettenkofen was present at the final defeat

14 Mihály Vörösmarty. 1854. 'The Old Gypsy’. Translated by Peter Zollman. https://www.visegradliterature.net/works/hu/ V\%C3\%B6r\%C3\%B6smarty_Mih\%C3\%A1ly-1800/A_v\%C3\%A9n_cig\%C3\%A1ny/en/2120-The_ancient_gypsy

See also the poem of Nikolaus Lenau, 'Die drei Zigeuner' (1838), among others. See more about the German context of the topic in Solms 2008. 
of the 1848 Hungarian War of Independence. In 1852-53, he lived in Paris and subsequently visited Szolnok, a Hungarian provincial town, where he spent summers for the next 30 years. With Lajos DeákÉbner, he was a precursor of the Szolnok Artists' Colony that flourished at the turn of the century. His later admirer Dezső Rózsaffy wrote in 1905:

It was their definite racial character, picturesque attire, flamboyantly original habits and lifestyle that attracted Pettenkofen to the Gypsies. The Gypsy is the Bedouin of the Great Plain. While dispossessed and poor as a dervish in the desert, having but a leaky tent, a hovel looking like a ground squirrel's hole, one or two nags and lots of children, they nevertheless rejoice and enjoy life. (...) His other favourite motif was a group of bathing Gypsy women and children. (...) A painting with an amicable subject is the Pig-thief. A Gypsy boy runs across the meadow carrying his loot, while dogs are chasing him. (...) There are also a couple of head studies. One example is a beautiful male head in red and brown with characteristic Gypsy features in the Modern Art Gallery of Vienna (Rózsaffy 1905 - translated by Róza Vajda, author's italics).

Moral disdain is only one step further from the stigmatisation of poverty. What Rózsaffy sees as a 'painting with an amicable subject' is based on the fundamental topos of theft, a core element of popular anti-Gypsy anecdotes. There is no need to analyse the above quotation line by line to identify suggestive parallels between 'Gypsy' and 'Black'.

I would like to dwell for a moment on Pettenkofen's study of a 'beautiful male head' (Figure 4) which brings to mind another artist, Pettenkofen's friend, Johann Gualbert Raffalt. Raffalt also appeared in Szolnok and became an acclaimed artist of the so-called 'Gypsy town', the fair, and the puszta - no wonder he often was referred to as Pußtamaler by his critics. 'It was a piece of East, an immediate Marrakesh, or Egypt, it carried in itself the nomad life and the chaos of the Puszta for those Viennese artists who got tired of pursuing the genre' (Rózsaffy 1905 - translated by Anna Lujza Szász). Quite possibly, the same 'Gypsy' families inspired him and his elder master. There is, nevertheless, something disturbing in both Pettenkofen and Raffalt's paintings (Figure 5), and what we do not see in the works of Hungarian artists at the time: aestheticised and staged representations of hysteria.

The two Austrian artists - 'strangers' themselves, though distinguished strangers in the empire - mingled the image of social exclusion in the Hungarian countryside which habitually was expressed by Hungarian artists: a portrayal of ragged clothes, dark skin, a man's bearded face, a woman's unkempt hair caught in the wind, the averted gaze of both, and the outward signs of living outside society with images of the savage, the agitated, and the hysteric. The stigmatising gaze cast by the 'strangers of the empire' shows an affinity not so much with contemporary art but with gross, indifferent, or even arrogant ideas of public poetry (Hegedüs 2004).

The bourgeois gaze of the turn of the century treats the 'Gypsies' as some strange and exotic tribe from the colonies (Dearing 2010). This has consequences for the representation of both male and female figures. On the one hand, the 'Gypsy man' per se is constructed, his otherness clearly manifest in his savage look, so that he does not need to wear the characteristic marks of his crafts as in earlier paintings. This savagery, 


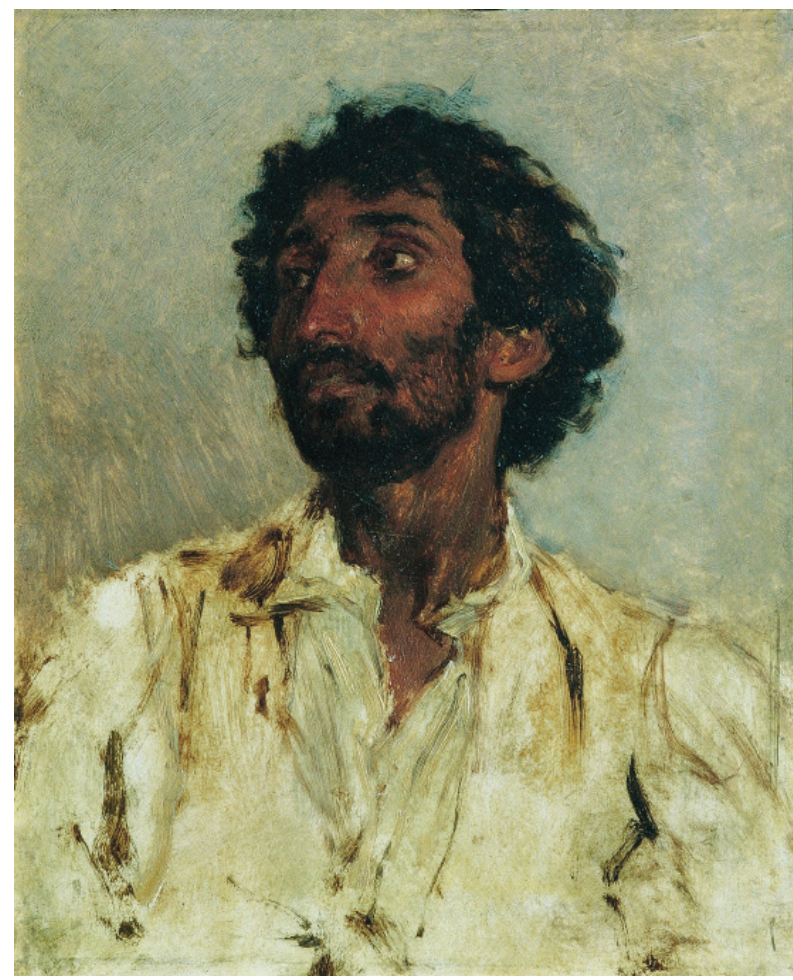

Figure 4.

August von Pettenkofen, Brustbild eines Zigeuners, c.1860, oil on wood, 23 x $19 \mathrm{~cm}$, Österreichische Galerie Belvedere, Wien.

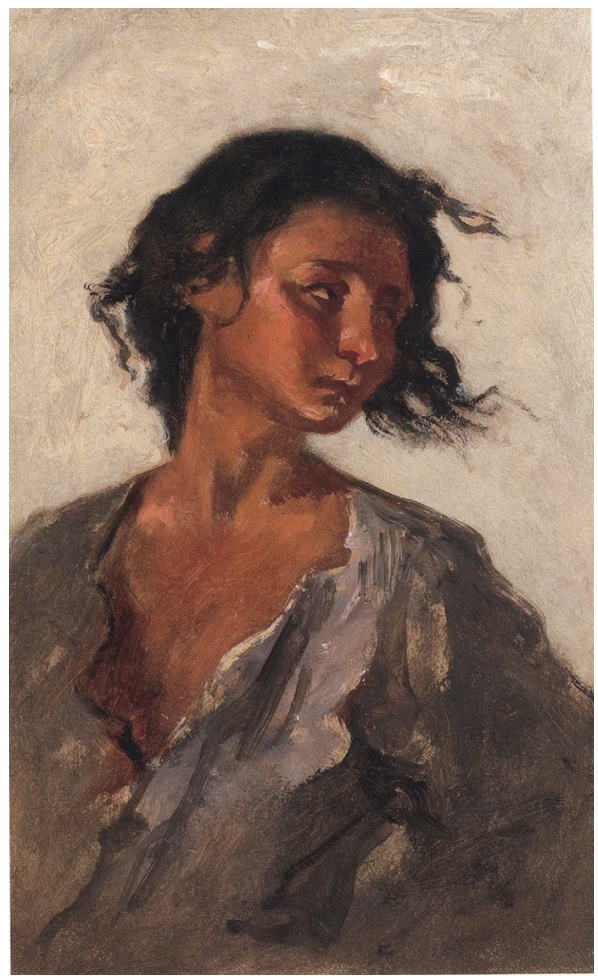

Figure 5.

Johann Gualbert Raffalt, Zigeunerin, c. 1855-60, oil on wood, 27 x $18 \mathrm{~cm}$, Neue Galerie am LM Joanneum, Graz.

so dangerous to the 'civilised' world, becomes interesting and beautiful when it appears in the arts. On the other hand, the 'Gypsy girl' or 'Gypsy woman' per se may serve as a target of paedophilia, sexual humiliation, and essentialism. The reminiscences of Lajos Kunffy, an artist working in the village of Somogytúr, provide an apt illustration of the artist's essentialising gaze as well as the synergies dominating contemporary European art:

In 1905, I started painting Gypsy pictures, mainly dark-complexioned, so-called trough-maker Gypsies with long hair tied at the front. I found these people particularly picturesque, sitting by their tents in summer time, preparing troughs and cooking, while the children were running around naked; together giving the impression of a primitive, ancient people. No doubt, they come from India. When Albert Besnard returned to France from his voyage in India and I saw his work, I told him there was no need to travel great distances as you can paint figures like that in Hungary, too. (...) Most of my Gypsy paintings have been sold since; I hardly have any left in my ownership. In a collective exhibition in Paris in 1913, where I still had many works with Gypsy themes on show, the daily Paris-Midi that reproduced some of these paintings called me 'le peintre des zigán'. But what had befallen these Gypsies? They were no longer wearing long hair. As a matter of fact, those drafted into the army in 1914 had their hair cut short. 
(...) They would come to me after the war, too, asking if I still wanted to paint them, without their long hair, as they liked the easy money. Lately, realising it was more comfortable this way, even children have ceased to wear long hair. Therefore, I stopped being that interested in men; I painted, instead, a couple of beautiful girls and the so-called Kolompár Gypsies whose outfit is a lot more colourful (Kunffy 2006, 108-109 - translated by Róza Vajda, author's italics).

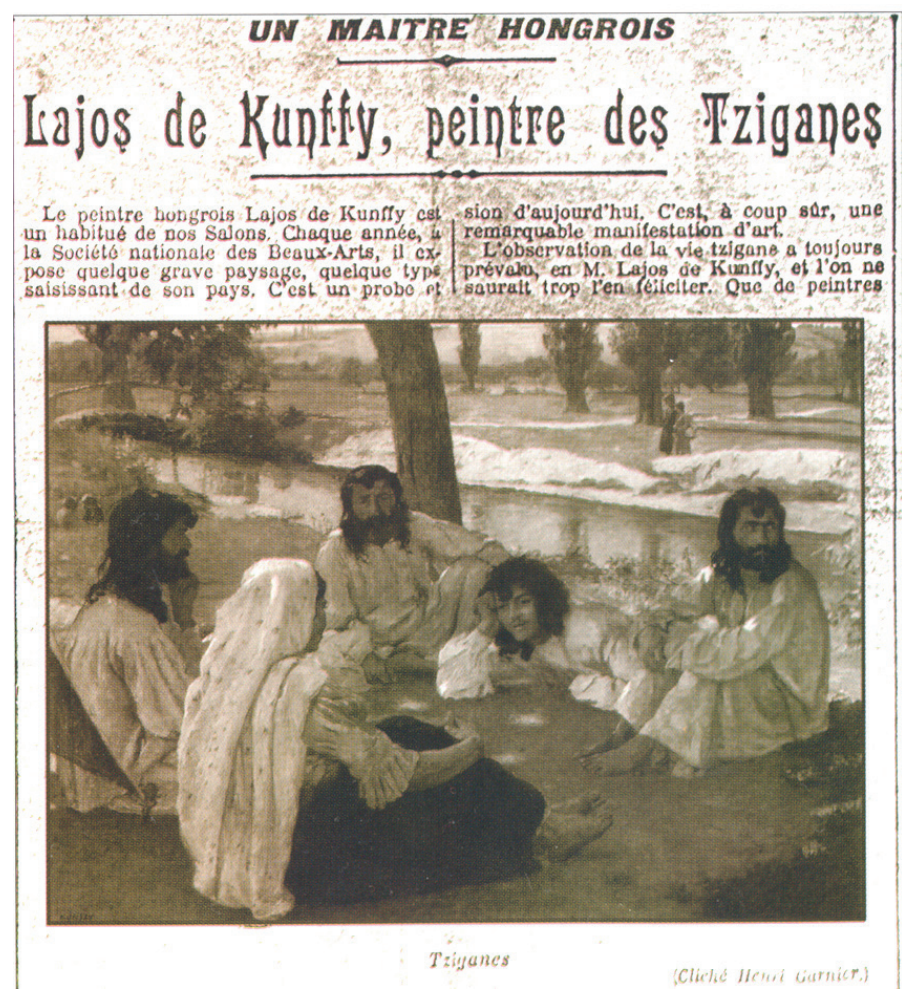

Figure 6.

Tabarant, 'Un maître Hongrois. Lajos de Kunffy, peintre des Tziganes'. Paris Midi, 29 January 1913.

Although the First World War prevented prevented Albert Besnard from making a trip to Hungary, Somogytúr turned into a small colony of Hungarian artists. Béla Iványi Grünwald, Lajos Szilányi, Aladár Edvi-Illés, and József Rippl-Rónai all visited Kunffy and portrayed Kunffy’s 'Gypsies' (Horváth 2006; Kunffy 2006). Apparently, creating 'Gypsy' images proved to be a lucrative business for Kunffy himself, whose reproduced works became accessible to a broader Parisian public (Figure 6). Nevertheless, although many of his models were living around his estate for many years, Kunffy fails to mention them or their families by name, both in his paintings with 'Gypsy' subjects and in his memoirs. Instead, his works carry titles in the fashion of Gypsy Girl, Gypsy Chief, and the like.

Meanwhile, life continued along the banks of Tisza, too. Leaving Wrocław and his professorship behind, Otto Mueller, a distinguished member of the Brücke group, whose Zigeunermappe - the title was not given by the author - became available only recently, used to spend some of his holidays in the 'Gypsy town' of Szolnok 
(Pirsig-Marschall 2004; Dearing 2010). He made photos and sketches on the spot, elaborating his topics in colourful lithographs upon his return home. According to some biographical sources, while on holiday, Otto Mueller lived among Roma and Sinti people. He entertained the idea that his ancestors may have been 'Gypsies' (Junghaus and Székely 2006) - which, however, was not confirmed by Tanja Pirsig-Marschall, a scholar who studied his oeuvre. Probably Otto Mueller was no more of a 'Gypsy artist' than Kunffy was le peintre des zigán. (What is known, however, is that Mueller prepared Negro and the Show Girl, a painting from 1903.) His famous works with 'Gypsy' subjects - evoking ancient Egyptian forms and colours that are much more delicate than those of his contemporaries - mainly consist of 'Gypsy' nudes painted in nature.

\section{Bodies Resuscitated and Appropriated: The Paedophile, the Sexist, and the Essentialising Gaze}

The passionate painting of nudes - often based on preliminary sketches and photographs like in the case of Otto Mueller - was a more precarious business than conventional plein air art because of the need for models (Reuter 2014). 'Expeditions' to the world of distant art colonies provided a viable solution; a case in point is the Nagybánya (Baia Mare, Romania) art school. Béni Ferenczy remembers:

Basically, only Gypsies were willing to show their naked bodies; miners' daughters and village girls would pose for nudes only in a state of debauchery, and even that did not last long as their brief career as models got bogged down in the local brothel or the one in Szatmár. The majority of Gypsy girls usually would be partially naked, undressed to the waist, or not even that. The most beautiful one, Eszter Krajcár, the card reader in my father's triad of Gypsies, would pose for anyone but only in clothes (Murádin and Szücs 1996, 201 - translated by Róza Vajda).

A half-grown girl looks at us with timid, inquisitive eyes from István Réti’s nudes of 1912/13; she is probably younger than any model of her kind in the history of modern art (Figure 7). These paintings by a renowned master of the famous Nagybánya art colony and a significant artist of twentieth century Hungarian painting are considered masterpieces by Hungarian art historians. However, almost a century later, it is the plight of the vulnerable child, rather than the artistic performance, that strikes the eye. Thus, it is incomprehensible why one should discover the 'joy and beauty of youth' in them (Szöllössy 2002, 78). Indeed, the longer we linger on this girl's figure the more we see Nabokov's Lolita

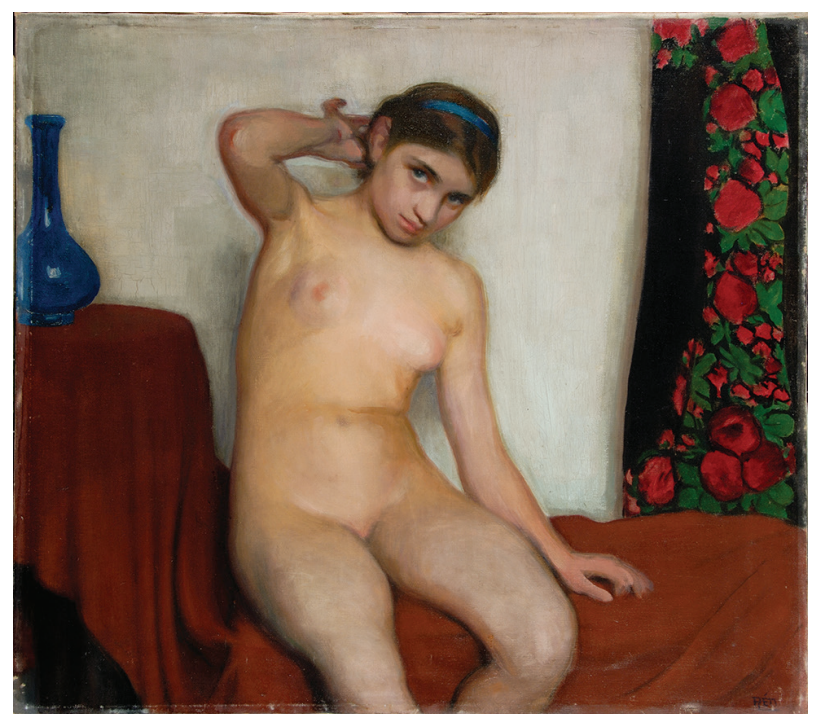

Figure 7.

István Réti, Gypsy Girl, 1912, oil on canvas, 80.5 x 91 cm, Hungarian National Gallery, Budapest. 
rather than a young woman. The title of the painting suggests so, too. The eyes of the adolescent girl reflect the dominant - so to speak, paedophile - male gaze: instead of eroticism, they suggest embarrassment, fear, and sexual vulnerability. Such an explicit infringement of social norms was possible only when oppressed ethnic or social groups were concerned - hard as I tried, I have not found a single similar composition by any contemporary Hungarian artist of a 'white' adolescent girl. Why this body is not white is another question. We might ask here how did meaning get shifted from 'peasant' to 'Gypsy'?

This question brings us back to the painting by Gölöncsér Gundel, a trigger of the present study (Figure 1). Art historian László Beke wrote about this piece:

Gundel Göröncsér's artwork may be considered a plein air work in typical Nagybánya style; however, its composition is more courageous and canny than Károly Ferency's paintings. Moreover, one feels like it conveys a strange, symbolic, or even allegorical sense. The dark silhouette figure in the shadowed foreground, contrasted with the female nude on the sunny waterfront - as if a snapshot taken from a film - thematise the Gypsy characters as a dualism of «heavenly and earthly love» or «intellectualism and sensualism» (Beke 2007, 74 translated by Róza Vajda).

Beke mentions 'Gypsy characters', and he is right: based on the iconography of the image and confirmed by the memoirs of Ferenczy, both women were 'Gypsy models'. Instructed by the title, however, we are required to see them as a 'Gypsy girl' and a 'nude model. The title refers to one of the bodies (the one in clothes) as a 'Gypsy', designating the other one (only) as a nude model. What does this title - that is perhaps erratic and expedient (hence, driven by the optical unconscious), or may be sophisticated just like the composition itself - add to the meanings of the painting? ${ }^{[15]}$

The similarities in clothes, hair colour, and style also suggest a kind of dialogue between the two bodies, a dynamic unity formed by the two women. The arch formed by the 'Gypsy girl's' forehead, nose, mouth, and chin is interlocked with the line created by the breasts, belly, and mons of the nude model. Viewed from this perspective, the painting looks like a first frame in a fictional motion picture on shame where the next frame will show the 'Gypsy girl' completely covering the nude model who, throwing her blouse onto the grass and raising her eyes that so far have been fixed modestly to the ground, will directly face us right at the moment when the 'Gypsy girl' casts an admonishing glance in our direction, while we, just like the nude, will be completely hidden at this point. In this fictional film, the 'Gypsy girl' and the nude model do not look at each other - they are ashamed of even being seen by one another.

There is another way of reading the painting, namely, as condensing the passing of time in a single image in which the moral integrity of the 'Gypsy' is at stake. This interpretation shows the immature and innocent Gypsy girl stepping from the shade into the light of the male gazes of the adult world, now with a mature 
and naked body. Thus, the nude model points back to the 'Gypsy girl', casting a shadow over her: 'You shall become like this!' This is how the body of the 'Gypsy' is exposed on the altar of a radical yearning for freedom in plein air art. Like other art historians Beke refrains from going beyond a thorough analysis of the conventional composition and the iconographic and decorative elements reflecting the period and the school in question and directly suggests that the dual figure should be read as the dualism of the World of Arts versus Earthly Life.

My interpretation differs but not because I inadequately move beyond art history. In fact, my question should be raised by art historians: What do 'Gypsy' and 'nude' refer to here? Saying that the naked 'Gypsy' body merely serves as a decorative element would be highly inappropriate. What kind of social relations allow beauty and shame to be incarnated by a 'Gypsy girl'? A response to this question leads to my second argument: Central European societies create their own Blackness through savage groups and individuals, distant and nearby colonies. In the Central European panoptic regime of Modernity 'Gypsies' become the pendants of the African and Asian 'primitives' of Western Europe.

\section{Transgressions and Exceptions}

This is how the optical unconscious of society is reflected in typical 'Gypsy' representations of Modernity. Yet, there are certain (and as far as I know unique) cases when multifaceted pro-Gypsy sensibilities and essentialist anti-Gypsy feelings - Romaphilia and Romaphobia - transgress the limits of 'Gypsy' as a cultural code and paradoxically come close to self-representation or even create a position to be taken by Roma artists later - even if no 'Gypsy' or Roma artists were known to be practicing fine art production at the time these paintings were created. An example of this is Gypsy with a Pipe by József Rippl-Rónai (Figure 8). Rippl-Rónai is said to have depicted one of Kunffy's models (Figure 9) when visiting in Somogytúr; in his painting Kunffy's beautiful beast is turned into a jovial gentleman.

My second example concerns a classical composition of Madonna with child by Lajos Tihanyi, where a white child is put into the dark hands of a 'Gypsy' woman (Figure 10). The third example could be Pál Jávor’s Gypsy Girl showing an elegant woman waking up (Figure 11). This composition draws attention to other motifs related to the embourgeoisement of the 'Gypsy': through the fine Japonism of the contours of the female body, hair style, and covered breasts, the figure of the Gypsy Girl is incorporated into the bourgeois world, while, at the same time, the image becomes Magyarised (nationalised) owing to the folkloristic context created by Hungarian motifs of a dinner plate, an embroidered damask tablecloth, and the painting on the wall.

The emancipating gaze described above is only one way of challenging the 'Gypsy' as a cultural code by resuscitating the 'Gypsy' body and involving it in a world of folklore or of the bourgeoisie, while still adhering to the conventions of the era, that is, applying the 'Gypsy' body simply as a decorative element in the picture. There was another, though extremely narrow, range within Romaphilia. This had nothing to do with the ethnographical or anthropological representations. A rare example of the turn produced by situational proximity or biographical dependency is János Valentiny, an 
artist who worked on Lipót Nádasdy's estate for almost a quarter of a century, starting from the second half of the nineteenth century, and created several paintings of Romani families from the village of Nádasd-Ladány. In Valentiny's paintings, the 'Gypsy' was neither displaced to become a

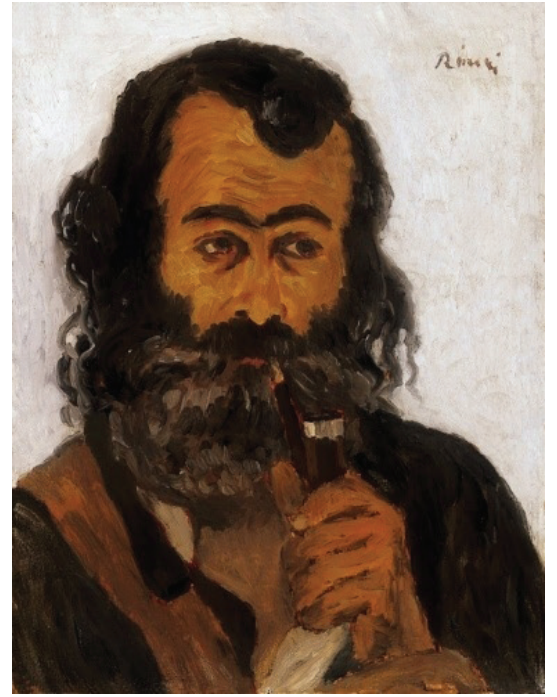

Figure 8.

József Rippl-Rónai, Gypsy with a Pipe, 1905, oil on wood, $41 \times 32 \mathrm{~cm}$, private collection. http://www.kieselbach.hu/alkotas/pipazocigany_-1905_4899

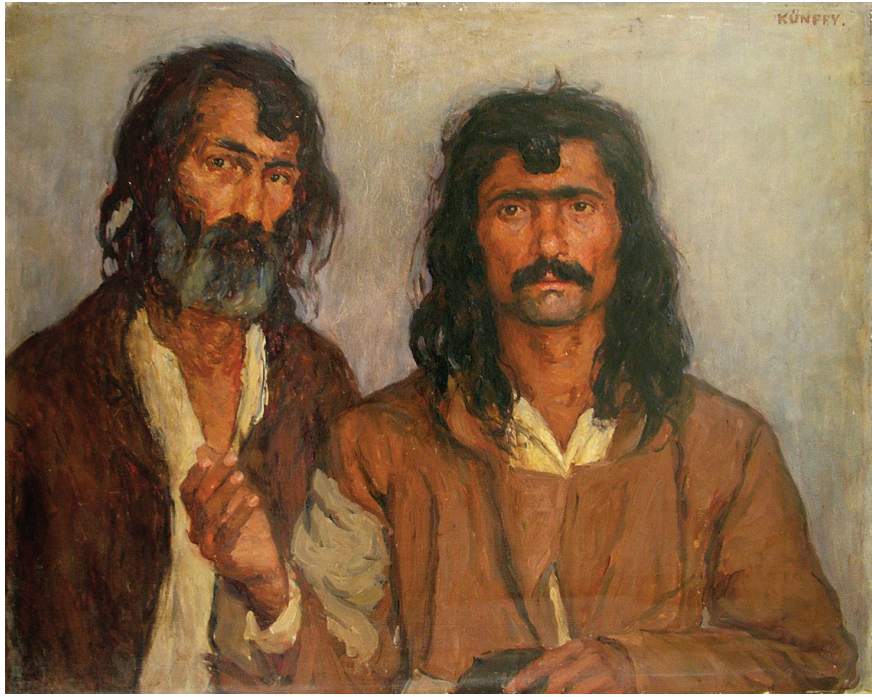

Figure 9.

Lajos Kunffy, Two Gypsies, 1910, oil on canvas, $73 \times 92 \mathrm{~cm}$, Kunffy Museum, Somogytúr.

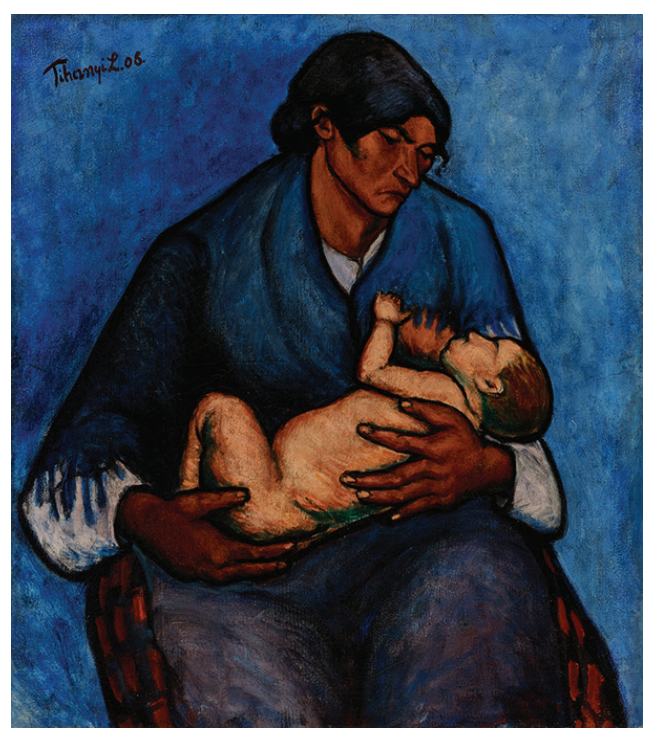

Figure 10.

Lajos Tihanyi, Gypsy Woman with Child, 1908, oil on canvas, $84 \times 75 \mathrm{~cm}$, Janus Pannonius Museum, Pécs.

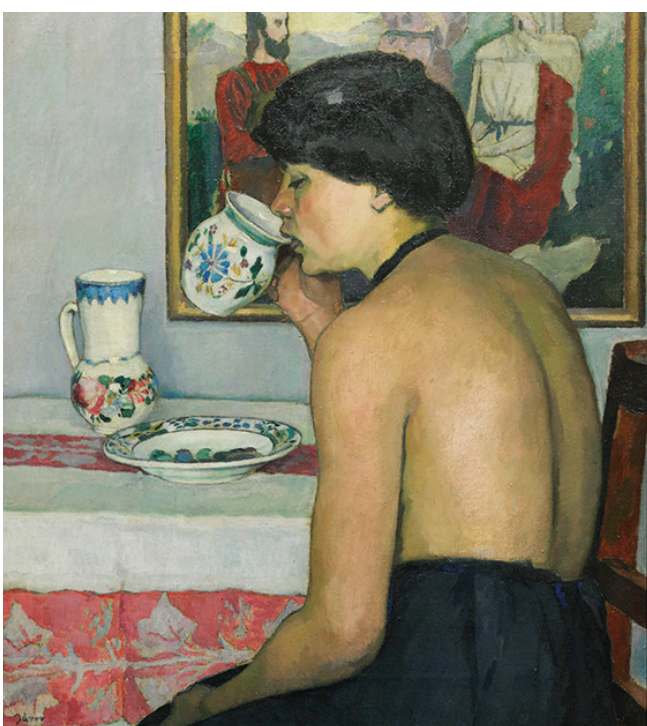

Figure 11.

Pál Jávor, Gypsy Girl, c. 1915, oil on canvas, $80 \times 71 \mathrm{~cm}$, Damjanich János Museum, Szolnok. 


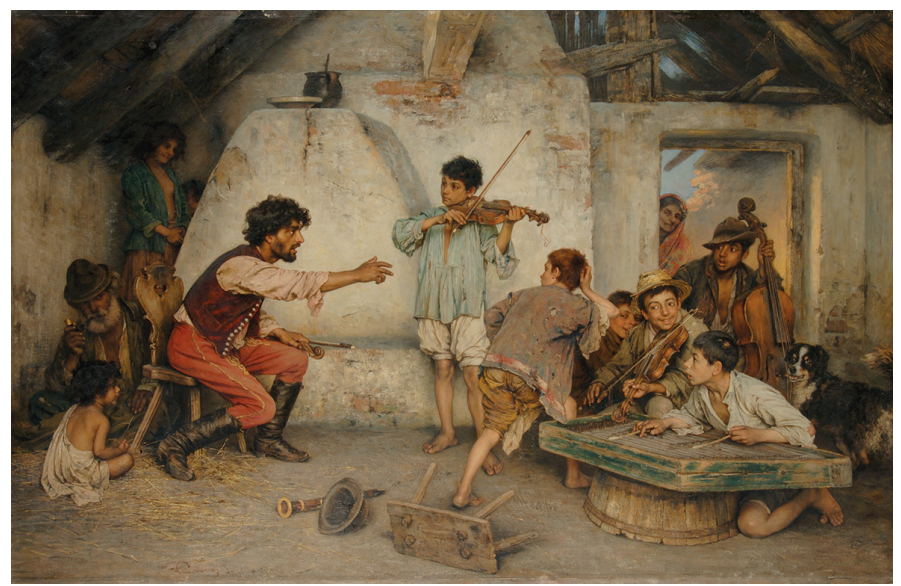

Figure 12.

János Valentiny, Gypsy School, 1896, oil on canvas, 129 x 197 cm, Hungarian National Gallery, Budapest. trope for the noble, the bourgeois, or the folkloric, nor were 'Gypsy' figures conferred a 'savage' look so as to confer an exotic appearance. Instead, Valentiny made loveable genre paintings, and in many of which he situated himself as an observer among Romani neighbours. Though an ahistorical exaggeration, I venture to say he drew the non-Gypsy world into that of Romani people as part of a proactive mission (Figure 12).

\section{Conclusion}

This article discussed the visual representation of Roma in Central European societies by citing examples of Austro-Hungarian painters. According to the central thesis of my essay, the panoptic regime of Modernity operated in a similar way in the two halves of the continent. On the one hand, this regime revisualised social differences; on the other, it brought the oppressed social and ethnic groups into sight and rendered the oppressors invisible. In the contextualisation of these developments, it also became apparent that, in the emerging Romani imaginary, the 'Gypsy' functioned as an ambiguous part of the patriotic self-image during nation-building in Central Europe. Recent studies on the social and cultural history of the Habsburg Empire in the nineteenth century stress not only the cultural diversity of its peoples but also the diversity produced by the empire itself in order to expand its control over them. The 'Gypsy' relegated to the physical and mental peripheries of society became, pars pro toto, a kind of people, and, vice versa, peripheral situations were recognised as 'Gypsy' spaces.

I also identified the main channels and agents of entanglement between the ideas of 'savages' in Western and Central Europe, specifically the sexualisation and feminisation of groups and individuals through their ethnic origin. It was argued that the images of body, gender, sin, deviance, and ethnicity were so confluent that they transformed the essentially feminine nature of hysteria to become a male attribute in the case of Roma (and Jews). Besides entanglements and similarities, certain differences are also remarkable, which resulted in a permanent tension between the colonial and emancipatory gazes in Romani representation. Yet, there are certain cases in which multifaceted pro-Gypsy sensibilities and essentialist anti-Gypsy feelings transgressed the limits of the 'Gypsy' as a cultural code and, paradoxically, came close to self-representation, or at least created a position to be taken by Roma artists later. 
While ideas, imaginations, and artists commuted between the Western and Eastern parts of Europe, their objects - stigmatised as 'nationless' travellers - were already settled and integrated in society. (In 1893, Hungarian authorities reported 3.2 per cent of 'Gypsies' as travellers; while 82 per cent of Romani working-age men were already part of the labour market.) Thus, it is quite likely that settled Romani families inspired all the non-Romani painters at the Szolnok and Nagybánya artists' colonies or on the estate of Kunffy in Somogytúr, respectively. However, it is almost impossible to reconstruct the names of these Romani models and present them as agents of my story. Apart from Eszter Krajcár from Nagybánya, artists' memoirs and correspondence hardly ever mentioned Romani models by their names. Two years ago, a colleague conducted a pilot project to trace the Romani families in the 'Gypsy-town' of Szolnok (Szász 2019). Her main task was 'to find out who the models were: to unfold their life stories and to offer them a place in history not only as empirical "objects" of art but also as "subjects" who are placed in power relations and are unique as well as embody agency, historical awareness, and autonomy' (Szász 2019). She could identify just some of names of possible models of the fin de siècle painters. For instance, in the middle of the 1950s, a local monthly published a short essay about the Szolnok art colony, in which the authors reported the death of György Nana - a model for Pettenkofen, János Bihari, and many other painters from the Szolnok art colony (Keszegh and Krámer 1955). In the archival files, many other names appeared. ${ }^{[16]}$ Further micro-historical research could provide ample opportunity to complement or rewrite my thought experiment by exceeding the limits of art history.

\section{Acknowledgments}

I would like to express my gratitude to Gerhard Baumgartner, László Beke, Tayfun Belgin, Éva Forgács, Anna Lujza Szász, Péter Szuhay, and Róza Vajda for their encouragement and criticism. I owe also special thanks to the anonymous reviewers whose comments have improved the manuscript greatly.

16 Here, I would also like to mention: János Nagyhajú, Lajosné Nagyhajú, Lászlóné Fazekas, Samu Rostás, Mária Pege, János Rozsár, Gábor Frigor, Pálné Rozsár, Józsefné Kadet, Róza Rozsár, Zsigmondné Rozsár, Lajos Horváth, István Nagyhajú, Béla Varga, Gáborné Horváth, Istvánné Nagyhajú, Sándorné Sántha, Lajos Frigul, Sándor Spiru, Mihályné Horváth, Piros Bagi, Lajos Szabó, Gusztáv Kóré, Rózsi G. Nagy, János Raffael, Menyhért Kállai, Sándor Horváth, Miklós Raffael, László Kiss, Péter Barna, Sándor Farkas, Lajosné Károlyi, István Kovács, Györgyné Balog, László Mondok, Sándor Kökény and Ferenc Göncző (Szász 2019). 


\section{References}

Altorjai B. Apor, Péter. 1978 [1736]. Metamorphosis Transilvaniae, edited by László Kócziány and Réka Lőrinczi. Bucharest: Kriterion.

Archer-Straw, Petrine. 2000. Negrophilia: Avant-Garde Paris and Black Culture in the 1920s. London: Thames \& Hudson.

Barthes, Roland. 1981. Camera Lucida: Reflections on Photography. New York: Hill and Wang.

Baumgartner, Gerhard, and Éva Kovács. 2007. 'Roma und Sinti im Blickfeld der Aufklärung und der bürgerlichen Gesellschaft'. In Roma und Sinti. 'Zigeuner-Darstellungen' der Moderne. Katalog zur Ausstellung, edited by Belgin and Baumgartner, 15-23. Krems: Kunsthalle Krems.

.2008. 'Zur Ikonographie der “Zigeunerbilder” der Moderne'. In Otto Pankok Sinti-Porträts 1931 bis 1949, edited by Eva Pankok and Romani Rose, 38-57. Berlin: Damm und Lindlar.

Beke, László. 2007. 'János Göröncsér Gundel'. In Roma und Sinti. 'Zigeuner-Darstellungen’ der Moderne. Katalog zur Ausstellung, edited by Belgin and Baumgartner, 74. Krems: Kunsthalle Krems.

Belgin, Tayfun, and Gerhard Baumgartner, eds. 2007. Roma und Sinti. 'Zigeuner-Darstellungen' der Moderne. Katalog zur Ausstellung. Krems: Kunsthalle Krems.

Belting, Hans. 2001. Bild-Anthropologie. Entwürfe für eine Bildwissenschaft. München: Wilhelm Fink Verlag.

_ 2012. 'Body and Image'. In Iconic Power. Cultural Sociology edited by Jeffrey C. Alexander, Dominik Bartmański, and Bernhard Giesen, 187-202. New York: Palgrave Macmillan.

https://doi.org/10.1057/9781137012869_12

Benjamin, Walter. 1980. Gesammelte Schriften. Band I, Teil 2, Frankfurt am Main: Suhrkamp.

Bernheimer, Charles. 1997. Figures of Ill Repute: Representing Prostitution in Nineteenth-Century France.

Durham: Duke University Prress.

Bitterli, Urs. 1976. Die «Wilden» und die «Zivilisierten»: Grundzüge einer Geistes- und Kulturgeschichte der europäisch-überseeischen Begegnung. München: C. H. Beck.

Bloom, Lisa. 1999. With Other Eyes: Looking at Race and Gender in Visual Culture. Minneapolis: University of Minnesota Press.

Buck-Morss, Susan. 2011. 'Visual Studies and Global Imagination'. The Politics of Imagination, edited by Chiara Bottici and Benoît Challand. London: Birkbeck Law Press.

Crary, Jonathan. 1990. Techniques of the Observer on Vision and Modernity in the Nineteenth Century. Cambridge/ Massachusetts/London: MIT Press.

Cséri, János Dr. 1893. Budapest fó- és székváros prostitútió ügye [The case of prostitution in the municipality of Budapest]. Budapest: Grill Károly cs. és kir. Udvari könyvkereskedése.

Dearing, Steward 2010. 'Painting the Other Within: Gypsies According to the Bohemian Artist in the Nineteenth and Early Twentieth Centuries'. Romani Studies 5 (20/2), 161-202.

Didi-Huberman, Georges. 1999. Ouvrir Vénus. Nudité, rêve, cruauté. Paris: Gallimard.

- 2003. Invention of Hysteria. Translated by Alisa Hartz. Cambridge, MA: MIT Press.

Ferrero, Guglielmo, and Cesare Lombroso,. 2004 [1893]. Criminal Woman, the Prostitute, and the Normal Woman. Durnham, NC: Duke University Press. 
Feichtinger, Johannes, Ursula Prutsch, and Moritz Csáky, eds. 2003. Habsburg postcolonial. Machtstrukturen und kollektives Gedächtnis. Innsbruck/Wien/München/Bosen: Studien Verlag.

Foucault, Michel. 1995. 'Panopticism'. In Discipline \& Punish: The Birth of the Prison, translated by Alan Sheridan, 195-228. New York: Vintage Books,.

Gelbart, Petra. 'Franz Liszt and the Making of Legends'. https://www.romarchive.eu/en/music/classical-music/ franz-liszt-and-making-legends

Gilman, Sander L. 1991. The Jew's Body. London: Routledge.

. 1985. 'Black Bodies, White Bodies: Toward an Iconography of Female Sexuality in Late NineteenthCentury Art, Medicine, and Literature.' Critical Inquiry 12 (1), 204-242.

Gjerden, Jorunn Svensen, Kari Jegerstedt, and Švrljuga, Željka, eds. 2019. Exploring the Black Venus Figure in Aesthetic Practices. Leiden/Boston: Brill/Rodopi.

Gombrich, Ernst H. 1999. 'Der Wert des Primitiven in der Kunst'. In Kunstwelten im Dialog. Von Gaugin bis zur globalen Gegenwart, edited by Marc Scheps, 26-37. Köln: Ludwig Museum.

Hamburger, Klára. 2011. Franz Liszt. Leben und Werk. Köln/Weimar/Wien: Böhlau.

Hárs, György Péter. 2006. 'Korreszpondenciák. Walter Benjamin és Ferenczi Sándor’ [Correspondences. Walter Benjamin and Sándor Ferenczi]. Thalassa (17) 2-3, 127-146.

Hegedűs, Sándor. 2006. Cigányábrázolás a magyar költészetben [Gypsy representation in Hungarian poetry] Piliscsaba: Konsept-H.

Horváth, János. 2006. Kunffy Lajos cigányképei [Gypsy images of Lajos Kunffy]. Kaposvár: Somogy Mezei Múzeumok Igazgatósága.

Junghaus, Tímea, and Katalin Székely. 2006. Meet Your Neighbours - Contemporary Roma Art From Europe. Budapest: Open Society Institute.

Keszegh, Istvánné, and Márta Krámer. 1955. 'A szolnoki művészet és művésztelep' [Art and the artists colony in Szolnok]. Jászkunság (2) 5, 23-26. http://epa.oszk.hu/03000/03002/00007/pdf/EPA03002_ jaszkunsag_195508_0204_023-026.pdf.

Klement, Judit, Ambrus Miskolczy, and András Vári, eds. 2006. Szomszédok világai. Kép, önkép és a másikról alkotott kép [Worlds of neighbours. Image, self-image and the image of the other]. Budapest: KSH.

Kovács, Éva. 2009. 'Fekete testek, fehér testek' [Black bodies, white bodies]. Beszélő (14) 1. http://beszelo.c3.hu/ cikkek/fekete-testek-feher-testek

Kövér, György. 2005. 'Hystériától a tébolyodottságig. Klára és Emma párhuzamos esettörténete' [From hysteria to insanity. Parallel stories of Klára and Emma]. Korall 21-22 (2005), 68-96.

Kunffy, Lajos. 2006. Visszaemlékezéseim [My memoirs], edited by János Horváth. Kaposvár: Somogy Mezei Múzeumok Igazgatósága.

La Mara [Marie Lipsius], ed. 1899. Franz Liszt’s Briefe. Leipzig: Breitkopf und Härtel. Bd. 4.

Lafferton, Emese. 2003. 'From Private Asylum to University Clinic: Hungarian Psychiatry, 1850-1908'. In Framing and Imagining Disease in Cultural History, edited by George S. Rousseau, Miranda Gill, David B. Haycock, and Malte Herwig, 190-213. New York: Palgrave Macmillan.

Lestringant, Frank. 1997. Cannibals. The Discovery and Representation of the Cannibal from Colombus to Jules Verne. London: Blackwell. 
Liszt, Franz. 1859. Des Bohémiens et de leur musique en Hongrie. Paris: Bourdillat.

Mathez, Philippe, Sylvain Froidevaux, Edina Földessy, and Diana Szántó, eds. 2008. A Másik. Évezredes hiedelmek, végzetes téveszmék, kulturális sokszinüség. Útmutató a kiállitáshoz [The Other. Millennial beliefs, fatal delusions, cultural diversity. A guide to the exhibition]. Budapest: Nemzeti Tankönyvkiadó.

Mátay, Mónika. 2005. 'Agycentizők a századfordulón' [Brain gaugers at the fin de sciècle]. Budapesti Negyed 47/48, 199-236.

Miskolczi, Ambrus. 2008. 'Miért éppen a cigányok?' [Why just the Gypsies?]. Holmi 2, 173-292.

Murádin, Jenő and György Szücs. 1996. Nagybánya 100 éve [Hundred years of Nagybánya]. Miskolc-Nagybánya: Herman Ottó Múzeum.

N. Kovács, Tímea. 2008. 'A világ háziura' [The master of the world] In: Az egzotikum [The Exotics] (edited by Zoltán Fejős), 23-37. Budapest/Szeged: Néprajzi Múzeum/SZTE Kommunikáció- és Médiatudományi Tanszék.

Oros-Klementisz, Marianna. 2008. 'Cigányok a képzőművészetben a vászon egyik és a másik oldalán’ [Gypsies in fine arts on both sides of the canvas] Barátság (15) 3, 5, 716-5,723.

Parent-Duchâtelet, Alexandre Jean Baptiste. 1837. De la prostitution dans la ville de Paris [...] 1836. Translated by Fr. Fleischer. Leipzig.

Pejić, Bojana. 1999. 'The Dialectics of Normality'. In After the Wall: Art and Culture in Post-Communist Europe, edited by Bojana Pejić and David Eliott, 116-28. Stockholm: Moderna Museet.

Piotrowski, Piotr. 2009. 'Toward a Horizontal History of the European Avant-Garde'. In Europa! Europa?, edited by Sascha Bru, Jan Baetens, Benedikt Hjartarson, Peter Nicholls, Tania Ørum, and Hubert van den Berg, 49-58. Berlin: De Gruyter. https://doi.org/10.1515/9783110217728.2.49

Pirsig-Marshall, Tanja. 2004. Otto Mueller and the Gypsies. PhD Thesis, University of Essex.

Reuter, Frank. 2014. Der Bann des Fremden. Die fotografische Konstruktion des 'Zigeuners'. Wallstein Verlag, 2014.

Rózsaffy, Dezső. 1905. “Pettenkofen Szolnokon” [Pettenkofen in Szolnok]. Müvészet 6, 386-399.

Sharpley-Whiting, T. Denean. 1999. Black Venus: Sexualized Savages, Primal Fears, and Primitive Narratives in French. Durham, NC: Duke UP.

Schlor, Joachim. 1991. Macht in der großen Stadt: Paris, Berlin, London 1840-1930. Düsseldorf: Artemis \& Winkler.

Schultz, Joachim. 1995. Wild, Irre und Rein. Wörterbuch zum Primitivismus. Gießen: Anabas.

Smith, Michelle, and Sharon Sliwinski. 2017 'Introduction'. In Photography and the Optical Unconscious, edited by Shawn Michelle Smith and Sharon Sliwinski, 1-31. Durham: Duke University Press.

Solms, Wilhelm. 2008. Zigeunerbilder. Ein dunkles Kapitel der deutschen Literaturgeschichte. Von der frühen Neuzeit bis zur Romantik. Würzburg: Königshausen \& Neumann.

Steer, Linda. 2017. Appropriated Photographs in French Surrealist Periodicals, 1924-1939. London: Routledge.

Szász, Anna Lujza. 2019. Naming the Bodies of Roma in Fine Art. https://www.romarchive.eu/en/visual-arts/romain-art-history/naming-bodies-roma-fine-art/\#fn2

Szöllössy, Ágnes. 2002. ‘Cigány a képen. Cigányábrázolás a XIX-XX. századi magyar képzőművészetben’ [Gypsy in the picture. Gypsy representation in the nineteenth- and twentieth-century Hungarian fine art]. Beszélő 7-8, $72-81$. 
Szuhay, Péter. 2002. 'Az egzotikus vadembertől a hatalom önnön legitimálásáig. A magyarországi cigányokról készített fotók típusai' [From the exotic savage to the self-legitimation of power. Types of photos taken of Hungarian Gypsies]. Beszélő 7-8, 97-106.

Thomas, Gregor. 2007. The Sexual Demon of Colonial Power: Pan-African Embodiment and Erotic Schemes of Empire. Bloomington, IN: Indiana University Press.

Timpano, Nathan J. 2017. Constructing the Viennese Modern Body: Art, Hysteria, and the Puppet. London: Routledge.

Wallace-Sanders, Kimberly, ed., 2002. Skin Deep, Spirit Strong: The Black Female Body in American Culture. Aberdon: University of Michigan Press.

Willis, Deborah, ed. 2010. Black Venus 2010: They Called Her 'Hottentot.' Philadelphia: Temple University Press. 